\title{
Biological Treatment of Broad Bean Hulls and its Evaluation through Tilapia Fingerlings (Oreochromis Niloticus) Feeding
}

\section{Malik M Khalafalla ${ }^{1 *}$ and EL-Sayed $B^{2}$}

${ }^{1}$ Department of Aquaculture, Faculty of Aquatic and Fisheries Sciences, Kafrelsheikh University, 33516 Kafr El-Sheikh, Egypt ${ }^{2}$ Agricultural Botany Department (Agric. Microbiology), Faculty of Agriculture, Kafrelsheikh University, 33516, Kafr El-Sheikh, Egypt

\begin{abstract}
Biological treatment of broad bean hulls by Pleurotus ostreatus and evaluation it through tilapia fingerlings (Oreochromis niloticus) feeding. The biological treatment show increased CP, NFE and GE content of broad been hulls comparing with the untreated as well as EE and CF decreased 27 and $43 \%$, respectively. DM and OM content decreased with $3.5-1 \%$, respectively. This bio-converted biomass was used as non-conventional feedstuff in diets of Nile tilapia fingerlings. The growth parameters recorded the highest values with nutrition of fish fed diet (3) containing $(50 \%)$ biodegraded broad bean hulls. The growth parameters also, recorded lowest values with nutrition of fish fed diet (5) containing (100\%) bio-degraded broad bean hulls. The same trend found on FCR, PER and PPV\% for diet (3) comparing with the other fed diets. It was observed that, the fish fed diet containing bio-degraded broad bean hulls at level (100\%) gave the lowest value comparing with the other treatments. Results showed no change in body composition content of Nile tilapia at the beginning and the end of the experimental for all the experimental diets.
\end{abstract}

Keywords: Biological treatment; Broad bean hulls; Oreochromis niloticus

\section{Introduction}

Tilapia is an ideal candidate for warm-water aquaculture. They spawn easily in captivity, use a wide variety of natural foods as well as formulated feeds, tolerate poor water quality, and grow rapidly at warm temperatures. These attributes, along with relatively low input costs, have made tilapia the most widely cultured freshwater fish in tropical and subtropical countries [1,2]. Tilapia is the most familiar and popular fishes in Egypt, as well as, in the Middle East and warm climate countries [3]. Nile tilapia is an important food fish that has been introduced to many different parts of the world by man [4]. Bridging the gap between the population and food production is one of the important tasks of developing countries. Expensive staple foods and policy constraints on food imports are the major factors worsening the food situation in developing countries [5]. Legumes have long shelf life and provide more proteins, abundant carbohydrates, high fiber, low fat (except oilseeds) and possess high concentration of polyunsaturated fatty acids. Legumes are also known for certain bioactive compounds, whose beneficial effects need to be explored for efficient exploitation. However, formulating economic tilapia feeds using unconventional, locally available feed resources remains a major challenge facing tilapia farmers, in general, and fish nutritionists, in particular. Several studies have been conducted to evaluate the incorporation of different unconventional animal and plant proteins and energy sources for farmed tilapia with varying results [6].

Many authors have shown that some fungi, particularly some species of Pleurotus are able to colonize different types of lignocellulsic wastes, increasing their digestibility [7,8]. Previous studies have shown the feasibility of using these kinds of wastes to produce animal feed [9], and as substrate for mushroom production [10].

The work was carried out to study the effect of biodegraded broad bean hulls by Pleurotus ostreatus, replacing there with $0,25,50,75$ and $100 \%$ of corn and wheat bran in the control diet as well as their efficacy on growth performance, feed utilization and body composition of Nile tilapia (Oreochromis niloticus) fingerlings.

\section{Materials and Methods}

This work was carried out at the Wet Fish Lab., Department of Animal Production and Botany Agricultural Department (Agricultural Microbiology), Faculty of Agriculture, Kafrelsheikh University. Feeding experiment was conducted for 14 weeks to study the effect of biodegraded broad bean hulls treated with Pleurotus ostreatus at five levels $(0,25,50,75$ and $100 \%)$ instead of corn and wheat bran in the control diet on growth performance, feed utilization and body composition of Nile tilapia (Oreochromis niloticus) fingerlings.

\section{Experimental fish}

Nile tilapia, Oreochromis niloticus fingerlings were brought from a fresh water commercial farm in Kafr El-Sheikh governorate, Egypt. Prior to the start of the experiment, fingerlings were placed in a fiberglass tank and randomly distributed into glass aquaria to be adapted to the experimental condition until starting the experiment. Fish was fed on the control diet for two weeks, during this period healthy fish at the same weight replaced diet ones. All the experimental treatments were conducted under an artificial photo period equal to natural light/darkness period (12 h light: $12 \mathrm{~h}$ darkness).

\section{Experimental design of rearing fish}

A total of 150 fish with an average initial body weight were $10.25 \mathrm{~g}$, were randomly stocked into 15 aquaria (70 liter). Each treatment was represented in three aquaria. Fresh tap water was stored in fiberglass tanks for $24 \mathrm{~h}$ under aeration for dechlorination. One third of water aquaria were replaced daily and totally once every week after removing

*Corresponding author: Malik M Khalafalla, Department of Aquaculture, Faculty of Aquatic and Fisheries Sciences, Kafrelsheikh University, 33516 Kafr El-Sheikh, Egypt, E-mail: malikkhalafalla@yahoo.com

Received March 04, 2015; Accepted May 13, 2015; Published July 15, 2015

Citation: Khalafalla MM, EL-Sayed B (2015) Biological Treatment of Broad Bean Hulls and its Evaluation through Tilapia Fingerlings (Oreochromis Niloticus) Feeding. J Aquac Res Development 6: 353. doi:10.4172/2155-9546.1000353

Copyright: ( 2015 Khalafalla MM, et al. This is an open-access article distributed under the terms of the Creative Commons Attribution License, which permits unrestricted use, distribution, and reproduction in any medium, provided the original author and source are credited. 
the wastes. Nine air stones were used for aerating the aquaria water. Water temperature ranged between $27-28^{\circ} \mathrm{C}$. Photoperiod was $14 \mathrm{hrs}$ per day using florescent light. Fish feces and feed residue were removed daily by siphoning.

\section{Experimental diets and feeding regime}

The broad bean hulls was treated by Pleurotous ostreatus using solid state fermentation technique performed by Belal [11] and Belal and Khlafalla [8] to improve its nutritive value. Stock culture of Pleurotous ostreatus was maintained on Potato Dextrose Agar at $4^{\circ} \mathrm{C}$.

Air dried milled biomass (50 gm from broad bean hulls) was placed in $500 \mathrm{ml}$ Erlenmeyer flasks, moistened with distilled water (65\%) and autoclaved at $121^{\circ} \mathrm{C}$ for $20 \mathrm{~min}$., cooled overnight and inoculated with 10 agar disks ( $5 \mathrm{~mm}$ diam.) from culture Pleurotous ostreatus (7 day old). After incubation for 20 day at $25 \pm 1^{\circ} \mathrm{C}$, the sterilized bioconverted substrates were used as inoculum for non-sterilized air dried milled biomass with rate $10 \%$ as follow:-

Each air dried milled biomass (broad bean hulls) was placed in glass box (width $40 \mathrm{~cm} \times 30 \mathrm{~cm}$ height), moistened (till 65\%) with water, the substrate moistened when needed. The biomass materials were treated with rate $10 \%$ from the described bioconverted substrate $(106 \mathrm{cfu} / \mathrm{gm})$, mixed well after that was covered by polyethylene and incubated for 42 days at $25 \pm 1^{\circ} \mathrm{C}[7,8]$.

Prior to the start of the experiment, the fish were adapted to a basal commercial diet [control diet (T1)] containing $30.11 \%$ crude protein and were consisted of herring fish meal, soybean meal, yellow corn and wheat bran for two weeks. Five experimental commercial diets were formulated to contain treated broad bean hulls at four levels $(25,50,75$ and $100 \%$ ) instead of yellow corn and wheat bran (Table 1). Each diet was fed to three randomly assigned aquaria.

A basal diet was formulated using the commercial ingredients. The dry ingredients were finely grounded. The ingredients were mixed by a dough mixer for 20 minutes for homogeneity. Oil was gradually added and mixed. After homogenous mixture, forty $\mathrm{ml}$ water per hundred gm diet was slowly added to the mixture according to Shimeino et al. [12]. The diets were cooked on the water evaporator for 20 minutes. The diets were pelleted $(3 \mathrm{~mm})$ through fodder machine and the manufacture pellets were dried on dried oven at $70^{\circ} \mathrm{C}$ for $48 \mathrm{hrs}$. The diets were collected and tagged and stored in refrigerator at $4^{\circ} \mathrm{C}$.

\begin{tabular}{|l|c|c|c|c|c|}
\hline \multirow{2}{*}{ Ingredients } & \multicolumn{5}{|c|}{ Diets $^{2}$} \\
\cline { 2 - 6 } & D1 (control) & D2 & D3 & D4 & D5 \\
\hline Fish meal & 10 & 10 & 10 & 10 & 10 \\
\hline Soybean meal & 45 & 45 & 45 & 45 & 45 \\
\hline Yellow corn & 26 & 20 & 14 & 8 & 2 \\
\hline Wheat bran & 14 & 10.5 & 7 & 3.5 & 0 \\
\hline Broad bean hulls & 0 & 9.5 & 19 & 28.5 & 38 \\
\hline Sunflower oil & 3 & 3 & 3 & 3 & 3 \\
\hline Vitam. and min. mix'. & 2 & 2 & 2 & 2 & 2 \\
\hline Total & 100 & 100 & 100 & 100 & 100 \\
\hline
\end{tabular}

'Vitamins composition/100 g mixture, VA (960000 IU), VD3 (160000 IU), VE (0.8 $\mathrm{g})$, VK $(0.16 \mathrm{~g}), V B_{1}(80 \mathrm{mg}), V B_{2}(0.32 \mathrm{~g}), V B_{6}(0.12 \mathrm{~g})$, Pantothenic acid $(0.8 \mathrm{~g})$, $\mathrm{VB}_{12}(0.8 \mathrm{mg})$, Niacin $(1.6 \mathrm{~g})$, Folic acid $(80 \mathrm{mg})$, Biotin $(4 \mathrm{mg})$ and Choline chloride $(40 \mathrm{~g})$. Composition of mineral mixture (gl100 g mixture). $\mathrm{MgSO}, 7 \mathrm{H}_{2} \mathrm{O}(12.75)$ $\mathrm{CaHPO}, 2 \mathrm{H}_{2} \mathrm{O}(72.85), \mathrm{ZnSO}, 7 \mathrm{H}_{2} \mathrm{O}(0.55), \mathrm{Ca}_{2} \mathrm{O} 6 \mathrm{H}_{2} \mathrm{O}(0.25), \mathrm{KCl}(0.02)$, FeSO $7 \mathrm{H}_{2} \mathrm{O}(5), \mathrm{CuSO}_{4} 5 \mathrm{H}_{2} \mathrm{O}(2.5), \mathrm{CuSO}_{4} 7 \mathrm{H}_{2} \mathrm{O}(0.08), \mathrm{CrCl}_{3} 6 \mathrm{H}_{2} \mathrm{O}(0.05), \mathrm{NaCl}(0.01)$ and Folic acid (6). (Local market).

${ }^{2}$ Diets: Diet 1 (Control diet), diets 2, 3, 4 containing 25, 50, 75 and 100\% treated broad bean hulls, respectively.

Table 1: Ingredients composition (\%) of the experimental diets.
Fish in all treatment were fed daily on the experimental diets at a level of $3 \%$ of the fish biomass then the fish were weighed every two weeks, the amount of feed were adjusted according to body weight. The fish were given the feed two times daily at (9.0 am and 3.0 p.m.).

\section{Analytical procedures}

Moisture, crude protein $(\% \mathrm{~N} \times 6.25)$, crude lipid, crude fiber and ash contents of diet ingredients and a sample of fish at the beginning and end of the experiment were determined in triplicate according to A.O.A.C [13] methods as follows: moisture was determined by ovendrying at $105^{\circ} \mathrm{C}$ for $24 \mathrm{~h}$; lipid by extracting the residue with $40-60^{\circ} \mathrm{C}$ petroleum ether for $16 \mathrm{~h}$; fiber as loss on ignition of dried lipid-free residues after digestion with $1.25 \% \mathrm{H}_{2} \mathrm{SO}_{4}$ and $1.25 \% \mathrm{NaOH}$; ash by ignition at $550-600^{\circ} \mathrm{C}$ to constant weight; total nitrogen by microKjeldahl method. Gross energy (GE) contents of the experimental diets and fish samples were calculated by using factors of 5.65, 9.45 and $4.22 \mathrm{kcal} / \mathrm{g}$ of protein, lipid and carbohydrates, respectively [14] for 14 weeks.

Measurements of water parameters:Water samples were taken each two days for ammonia and $\mathrm{pH}$ analysis. Analytical methods were done according to the American Public Health Association [15]. The $\mathrm{pH}$ values were determined by (A digital $\mathrm{pH}$-meter). Water temperature and oxygen level were measured daily at 8 o'clock by (Oxygen meter model 9070). In all treatments water quality parameters for water temperature ranged between 27 to $28^{\circ} \mathrm{C}, \mathrm{pH}$ (7 to 7.68); dissolved oxygen $(6.11$ to $6.75 \mathrm{mg} / \mathrm{L})$ and water ammonia $(0.05$ to $0.0 .08 \mathrm{mg} / \mathrm{L})$. All the water quality parameters were within the acceptable ranges for fish growth [16].

\section{Measurements of growth and feed utilization parameters}

Body weight of fish in each aquarium was measured at start and every two weeks during the experimental period (14 weeks). Diet performance was evaluated as follows:

- Average weight gain AWG (g/fish)=Wt-W0.

- Average daily weight gain ADG (g/fish/day)=Wt-W0/t.

- Specific growth rate\% day SGR $(\% /$ day $)=100 \times($ In Wt-InW0 $) / t$

- ${ }^{*}$ Where $\mathrm{Wt}$ is weight of fish at time $\mathrm{t}, \mathrm{W} 0$ is weight of fish at time 0 , and $t$ is the experimental period in days.

- Feed conversion ratio, FCR=dry feed fed/wet weight gain.

- Protein efficiency ratio, PER=wet weight gain/Protein fed.

- Protein productive value, PPV $(\%)=100 \times($ protein gain/protein fed $)$

- Survival rate, $\mathrm{SR}=100$ (Total No. of fish at the end of the experimental/Total No. of fish at the start of the experiment].

Statistical analysis:

The obtained numerical data were statistically analyzed using SPSS [17] for one-way analysis of variance. When F-test was significant, least significant difference was calculated according to Duncan [18].

\section{Results and Discussion}

\section{Broad bean by-products}

The chemical composition of treated and untreated broad bean hulls used in diets was shown in Table 2. The results revealed that, the CP content increased with $53 \%$ comparing with the untreated materials followed by NFE that increased $11 \%$ while, ash and GE 
Citation: Khalafalla MM, EL-Sayed B (2015) Biological Treatment of Broad Bean Hulls and its Evaluation through Tilapia Fingerlings (Oreochromis Niloticus) Feeding. J Aquac Res Development 6: 353. doi:10.4172/2155-9546.1000353

Page 3 of 5

\begin{tabular}{|c|c|c|c|c|c|c|c|c|}
\hline \multirow[t]{2}{*}{ Ingredients } & \multirow[t]{2}{*}{ DM\% } & \multicolumn{6}{|c|}{ (On DM basis, \%) } & \multirow{2}{*}{$\begin{array}{c}\text { GE}^{*} \\
\text { Kcal/g }\end{array}$} \\
\hline & & OM & CP & EE & CF & Ash & NFE & \\
\hline \multicolumn{9}{|c|}{ Untreated } \\
\hline Broad bean hulls & 93.78 & 85.24 & 9.52 & 9.87 & 20.47 & 12.52 & 47.62 & 4.22 \\
\hline \multicolumn{9}{|c|}{ Treated } \\
\hline Broad bean hulls & 90.54 & 84.33 & 14.57 & 7.20 & 11.67 & 13.44 & 53.12 & 4.12 \\
\hline
\end{tabular}

*GE (Gross energy) was calculated according to NRC (1993) by using factors of 5.65, 9.45 and $4.22 \mathrm{~K}$ cal per gram of protein, lipid and carbohydrate, respectively.

Table 2: Proximate Chemical analysis (\%) of untreated or treated broad bean hulls used in diets (\% on DM basis).

\begin{tabular}{|c|c|c|c|c|c|}
\multirow{2}{*}{ Item } & Control (D1) & \multicolumn{4}{|c|}{ Levels of treated broad bean hulls (\%) } \\
\cline { 3 - 6 } & & $\mathbf{2 5}$ (D2) & $\mathbf{5 0}$ (D3) & $\mathbf{7 5}$ (D4) & $\mathbf{1 0 0}$ (D5) \\
\hline DM (\%) & 91.20 & 92.14 & 92.54 & 92.67 & 92.95 \\
\hline OM (\%) & 93.16 & 93.26 & 93.42 & 93.13 & 92.90 \\
\hline CP (\%) & 30.11 & 30.87 & 31.42 & 31.93 & 31.98 \\
\hline EE (\%) & 8.87 & 8.54 & 8.44 & 8.79 & 9.13 \\
\hline CF (\%) & 5.68 & 5.98 & 6.27 & 6.88 & 7.12 \\
\hline Ash (\%) & 6.54 & 6.74 & 6.58 & 6.87 & 7.10 \\
\hline NFE (\%) & 48.80 & 47.87 & 47.29 & 45.53 & 44.67 \\
\hline GE (Kcal/g) & 4.59 & 4.57 & 4.57 & 4.56 & 4.50 \\
\hline
\end{tabular}

*GE (Gross energy) was calculated according to NRC (1993) by using factors of $5.65,9.45$ and $4.22 \mathrm{~K}$ cal per gram of protein, lipid and carbohydrate, respectively.

Table 3: Proximate chemical analysis (\%) of the experimental diets used in the experiment.

slightly increased. On the other hand, EE and CF decreased by 27 and $40 \%$, respectively. DM and OM content decreased 3.5 and $1 \%$. The same trend was also reported by Valizadeh et al. [19] indicated $\mathrm{CP}$ content increased significantly $(\mathrm{p}<0.05)$ after mushroom growing, from $46.6 \mathrm{~g} / \mathrm{kg}$ on zero day to $50.90 \mathrm{~g} / \mathrm{kg}$ after 84 days. DM content was low for wheat straw. OM content significantly decreased from 91.14 to $84.47 \%$ at the end day of mushroom. NDF content of the wheat straw were $719,690,669,612$ and $550 \mathrm{~g} / \mathrm{kg}$ for the day $0,21,42,63$ and 84 after seeding, respectively. A Similar tendency was found for ADF 474, $456,443,416$ and $387 \mathrm{~g} / \mathrm{kg}$ for the respective samples. These results are in agreement with the finding of Rzedzicki et al. [20] and Rzedzicki and Sobota [21]. Moreover, Broudiscou et al. [22] mushrooms are able to degrade between 25 and $60 \%$ of the dry weight of plant tissues although their efficiency varies according to the species, yield strain and the plant type. Williams et al. [23] found that biological treatment for straw produced more free sugars, more protein and gave less cellulose as well as lignin with an increase content of ash comparing with the untreated materials.

\section{Chemical composition of diets}

Chemical composition and calculated gross energy of different experimental diets are presented in Table 3 . The chemical composition of the experimental diets showed limited variations among these diets, it contained nearly similar DM, OM, CP, EE, CF, Ash, NFE and GE content. The DM content ranged from 91.20 to 92.95 ; OM from 93.13 to 92.90 ; CP from 30.11 to 31.98; EE from 8.44 to 9.13; CF from 5.68 to 7.12 ; ash from 6.58 to 7.10 and NFE from 44.67 to $48.50 \%$. The corresponding value of GE ranged from 4.50 to $4.57 \mathrm{kcal} / \mathrm{g}$. The data revealed that both of $\mathrm{CF}$ and ash content increased by increasing levels of treated broad bean hulls, while the NFE content decreased. The relatively high fiber content is limiting in its use in tilapia feeds because these fishes are lack in their ability to secrete cellulose which is the main cellulose digesting enzyme $[24,25]$. The biological treatment reduces its fiber contents and improves its nutritive value for fish feeding. Similar results reported by Hassanen et al. [26]. These values were within the range suggested for tilapia by Jauncey and Ross [27] and NRC [14].

\begin{tabular}{|c|c|c|c|c|c|c|}
\hline \multirow[t]{2}{*}{ Diet No. } & \multicolumn{2}{|c|}{ Body weight } & \multirow{2}{*}{$\begin{array}{l}\text { Total weight } \\
\text { gain (g/fish) }\end{array}$} & \multirow{2}{*}{$\begin{array}{c}\text { ADG } \\
(\mathrm{g} / \mathrm{fish} / \text { day })^{3}\end{array}$} & \multirow{2}{*}{$\begin{array}{c}\text { SGR } \\
(\% / \text { day })^{4}\end{array}$} & \multirow[t]{2}{*}{ SR $\%^{5}$} \\
\hline & $\begin{array}{c}\text { Initial } \\
\text { (g/fish) }\end{array}$ & $\begin{array}{c}\text { Final } \\
\text { (g/fish) }\end{array}$ & & & & \\
\hline 1 & 10.25 & $39.47 \mathrm{ab}$ & $29.22 \mathrm{ab}$ & $0.30 \mathrm{ab}$ & $1.38 \mathrm{bc}$ & 100 \\
\hline 2 & 10.26 & $41.84 \mathrm{ab}$ & $31.58 a b$ & $0.32 a b$ & $1.43 b$ & 100 \\
\hline 3 & 10.26 & $43.90 \mathrm{a}$ & $33.64 \mathrm{a}$ & $0.34 \mathrm{a}$ & $1.48 \mathrm{a}$ & 100 \\
\hline 4 & 10.22 & $42.36 \mathrm{a}$ & $32.14 \mathrm{a}$ & $0.33 a$ & $1.45 b$ & 96.67 \\
\hline 5 & 10.24 & $37.78 \mathrm{~b}$ & $27.54 b$ & $0.28 \mathrm{~b}$ & $1.33 c$ & 93.33 \\
\hline Mean & 10.25 & 41.07 & 30.82 & 0.31 & 1.42 & 98 \\
\hline $\mathrm{SE}^{1}$ & 0.24 & 2.11 & 1.78 & 0.02 & 0.16 & 3.25 \\
\hline
\end{tabular}

${ }^{1}$ Standard error of the mean derived from the analysis of variance. ${ }^{2}$ TWG (g/fish)=Average final weight $(\mathrm{g})$-Average initial weight $(\mathrm{g})$. ${ }^{3} \mathrm{ADG}(\mathrm{g} / \mathrm{fish} /$ day $)=[$ ATG $(\mathrm{g}) /$ experimental period $(\mathrm{d})]$.

${ }^{4} \mathrm{SGR}(\% /$ day $)=100$ (Ln final weight-Ln initial weight)/experimental period (d). ${ }^{5} \mathrm{SR}=100[$ Total No of fish at the end of the experimental/Total No of fish at the start of the experiment].

Table 4: Effect of using treated broad bean on growth performance parameter of (O. niloticus) fingerlings.

\section{Growth performance and surviving rate:}

The growth performance parameters of Nile tilapia (Oreochromis niloticus) fingerlings which fed diets contained with treated broad bean hulls $(0,25,50,75$ and 100\%) are shown in Table 4 as (initial and final) weights, average weight gain, average daily gain, specific growth rate and survival rate. Average of initial body weight of Nile tilapia fingerlings fed the experimental diets at the start did not differ, indicating that groups were homogenous. At the end of the experimental period (98 days), the final body weight of the fish groups fed on diets 3 and 4 had significantly $(\mathrm{P}<0.05)$ higher final body weight than the other groups. However, the lower growth performance found for the fish fed diet (5) contain $100 \%$ treated broad bean hulls; this may be due to the higher crude fiber content (7.12\%). On the other hand, the fish fed on diets 3 and 4 had significantly $(\mathrm{P}<0.05)$ higher TWG and ADG than the different groups.

Abdolsamad et al. [28] reported that replacement of native starch by gelatinized starch improved faces removal rate, growth and digestibility $(\mathrm{P}<0.01)$, but reduced fermentation $(\mathrm{P}<0.05)$ at the end of the intestine. Addition of gelatinized starch did not change viscosity and dry matter of the digest at the end of the intestine. A high level of starch in the fish diet also increased digestibility, growth and faces removal percentage $(\mathrm{P}<0.05)$. Fermentation and dry matter content at the end of the intestine were not influenced by a high starch diet, but viscosity was higher at the high level of starch inclusion. Volatile fatty acid levels in the stomach of Nile tilapia were high in the treatments with gelatinized starch. Gouveia and Davies [29] evaluated the use of a pea seed derived meal in experimental diets for European sea bass fingerlings of initial weight $10 \mathrm{~g}$. It was demonstrated that up to $40 \%$ pea seed meal inclusion was feasible in diets allowing for a $12 \%$ reduction in fish meal content and a $25 \%$ substitution of carbohydrate 


\begin{tabular}{|c|c|c|c|c|}
\hline \multirow{2}{*}{ Diet No. } & \multirow{2}{*}{ Feed intake (g/fish) } & \multirow{2}{*}{ Feed conversion ratio ${ }^{2}$ (FCR) } & \multicolumn{2}{|c|}{ Protein utilization } \\
\hline & & & Protein efficiency ratio 3 (PER) & Protein productive value ${ }^{4}$ (PPV, \%) \\
\hline 1 & 47.91 & $1.64 \mathrm{ab}$ & $2.02 \mathrm{c}$ & $26.86 \mathrm{bc}$ \\
\hline 2 & 47.63 & $1.51 \mathrm{~b}$ & $2.15 a b$ & $28.61 \mathrm{~b}$ \\
\hline 3 & 46.99 & $1.40 \mathrm{c}$ & $2.28 \mathrm{a}$ & $31.64 \mathrm{a}$ \\
\hline 4 & 46.45 & $1.45 \mathrm{bc}$ & $2.17 \mathrm{ab}$ & $29.92 a b$ \\
\hline 5 & 47.55 & $1.73 \mathrm{a}$ & $1.80 \mathrm{~cd}$ & $25.96 \mathrm{c}$ \\
\hline Mean & 47.32 & 1.55 & 2.08 & 28.60 \\
\hline $\mathrm{SE}^{1}$ & 2.24 & 0.12 & 0.14 & 1.84 \\
\hline
\end{tabular}

${ }^{1}$ Standard error of the mean derived from the analysis of variance.

${ }^{2} \mathrm{FCR}=\mathrm{DM}$ Feed Intake (g)/Live weight gain $(\mathrm{g})$.

${ }^{3}$ PER=Live weight gain $(\mathrm{g}) /$ Protein intake $(\mathrm{g})$.

${ }^{4} \mathrm{PPV}(\%)=100$ [Final fish body protein $(\mathrm{g})$-Initial fish body protein $\left.(\mathrm{g})\right] /$ crude protein intake $(\mathrm{g})$.

Table 5: Effect of using treated broad bean hulls on feed and nutrients utilization parameter of (O. niloticus) fingerlings.

\begin{tabular}{|c|c|c|c|c|c|}
\hline Diet No & Dry Matter & \multicolumn{3}{|c|}{ \% On dry matter basis } & Energy Content \\
& $(\%)$ & Crude Protein & Ether Extract & Ash & (Kcal/100 g) \\
\hline Initial fish & 19.52 & 60.12 & 15.17 & 20.15 & 502.28 \\
\hline 1 & 23.73 & $54.19^{\mathrm{b}}$ & 18.45 & 22.50 & 501.04 \\
\hline 2 & 23.23 & $55.62^{\text {ab }}$ & 19.27 & 23.55 & 502.94 \\
\hline 3 & 24.00 & $55.76^{\text {ab }}$ & 19.32 & 23.56 & 503.36 \\
\hline 4 & 23.96 & $55.54^{\text {ab }}$ & 18.98 & 22.81 & 504.43 \\
\hline 5 & 24.12 & $56.78^{\mathrm{a}}$ & 19.11 & 23.41 & 504.35 \\
\hline Mean $^{2}$ & 23.81 & 55.58 & 19.03 & 23.17 & 503.22 \\
\hline
\end{tabular}

${ }^{1}$ Diet 1 (Control diet), diets 2, 3, 4 containing 25, 50, 75 and $100 \%$ treated broad bean hulls, respectively.

${ }^{2}$ The mean in the same column bearing different superscript are significantly different at $(P<0.05)$.

Table 6: Body composition (\%) of Nile tilapia affected by feeding different diets(On DM basis).

content without appreciable loss in growth performance of juvenile sea bass or diet utilization.

\section{Feed intake and nutrient utilization}

Nutrient utilization in terms of feed intake (FI), feed conversion ratio (FCR), protein efficiency ratio (PER) and protein productive value (PPV\%) are illustrated in Table 5. Data showed that, there were no significant differences $(\mathrm{P}>0.05)$ between control group and all dietary experiments for FI, where it ranged between 46.45 and 47.91 g. Azaza et al. [30] indicated that there was no significant difference in feed intake among fish fed with the control feed and feeds containing 10 to $20 \%$ DSBM (dried soybean meal). The same trend was also reported by Gouveia and Davies [29] who indicated that the substitution of pea meal in the test diets between 20 and $40 \%$ and could be considered as an intermediate protein-energy supplement in the ration, there were no palatability problems and feed intake compared to favorably the reference fish meal diet.

The obtained results illustrated also that, the FCR, PER and PPV\% were high significantly $(\mathrm{P}<0.05)$ for fish fed diet $(3)$ containing $50 \%$ treated broad bean hulls comparing with the other fed diets. While fish fed diet (5) containing 100\% treated broad bean hulls had the lowest value. Average of FCR of the different diets was 1.64, 1.51, 1.40, 1.45

and $1.73 \mathrm{~kg}$ feed for each $\mathrm{kg}$ gain for $0,25,50,75$ and $100 \%$ treated broad bean hulls, respectively. The average of PER and PPV\% were $2.02,2.15,2.28,2.17$ and 1.80 for PER and PPV was 26.86, 28.61, 31.64, 29.92 and $25.96 \%$ for $0,25,50,75$ and $100 \%$ of treated broad bean hulls, respectively. The fish fed diet containing $100 \%$ treated broad bean hulls was the lowest values. While, the groups of fish fed diets containing $50 \%$ (D3) treated broad bean hulls higher values than other treatments.
Abdolsamad et al. [28] reported that increasing the starch content of the diets resulted in an increased growth $(\mathrm{P}<0.001)$ and a higher FCR $(\mathrm{P}<0.01)$. Moreover, Leary and Lovell [31] indicated that the excessive fiber in aquaculture diets may also lead to a decrease in feed utilization by obstructing the action of digestive enzymes and diluting nutrient density. Shalaby [32] studied that the effects of different levels of fenugreek seeds meal (FSM) $0,2,4,6$ and $8 \%$ of FSM on growth performance, feed and nutrients utilization as well as body composition. Results showed that fish fed diets containing 2\% FSM had significantly higher $(\mathrm{P}<0.05)$ body weight, weight gain, SGR, FCR and PER than those of fed the control diet and the other supplemented fenugreek seed levels. However, FSM levels of 6 and $8 \%$ gave significantly $(\mathrm{P}<0.05)$ lower growth performance parameters, FCR, PER and PPV\% than the control diet.

\section{Body composition and energy content of Nile tilapia}

Body chemical composition; DM, CP, EE, Ash and energy content of Nile tilapia at the beginning and the end of the experimental are shown in Table 6). There was no change in whole body composition among all experimental diets except CP content which significantly $(\mathrm{P}<0.05)$ increased by incorporation of treated broad bean hulls. Shalaby [32] studied the effects of different levels of fenugreek seeds meal (FSM) 0, 2, 4, 6 and 8\% of FSM on body composition. Results showed that no significant differences $(\mathrm{P}>0.05)$ were observed in moisture, crude protein, ether extract, ash and energy content of Nile tilapia fed diets containing various levels of FSM

Azaza et al. [30] studied the possible use of broad bean meal (FBM) in juvenile Nile tilapia-practical diets by progressively increasing its inclusion level (12, 24 and 36\%) at the expense of dehulled soybean meal (DSBM) in isonitrogenous $(27.5 \%)$ and isoenergetic formulated diets. Carcass composition was not clearly affected by diet composition. There were no differences in carcass protein content among the treatments. Carcass water content was significantly higher in fish fed the diet contains $36 \%$ FBM than those fed the other diets, and the lowest values were recorded in fish fed the control diet. A tendency was noted for body lipid level to decrease as FBM content increased in the diets. The fish fed the diet containing 36\% FBM had significantly lower body lipid than those fed the other diets ( $p>0.05)$. The body ash content did not vary significantly among treatments.

\section{Conclusion}

From the obtained results it could be found that, the biological treatment increased CP content of broad bean hulls by about more than $53 \%$ comparing with the untreated materials followed by NFE 
Citation: Khalafalla MM, EL-Sayed B (2015) Biological Treatment of Broad Bean Hulls and its Evaluation through Tilapia Fingerlings (Oreochromis Niloticus) Feeding. J Aquac Res Development 6: 353. doi:10.4172/2155-9546.1000353

that increased about $11 \%$ while, ash and GE slightly increased. On the other hand, EE and CF decreased by proximally 27 and $40 \%$, respectively. DM and OM content slightly decreased (3.5-1\%). Treated broad bean hulls could be successfully replacement as a feed for feeding Oreochromis niloticus fingerlings especially at levels of 50\% instead of corn and wheat bran without any adverse effects on their productive performance.

\section{References}

1. Tsadik GG, Bar AN (2007) Effects of feeding, stocking density and waterflow rate on fecundity, spawning frequency and egg quality of Nile tilapia, (Oreochromis niloticus). Aquaculture 272: 380-388.

2. Tahou AMA (2007) Studies on some factors affecting the production and reproduction of Nile tilapia.

3. El-Sherif MS, El-feky AMI (2009) Performance of Nile Tilapia (Oreochromis niloticus) Fingerlings .I. Effect of pH. Int J Agric Biol 11: 297-300.

4. Belal EB, Khalafalla MME, El-Hais AMA (2012) Use of Spirulina (Arthrospira fusiformis) for promoting growth of Nile Tilapia fingerlings. Afr J Microbiol Res 6: 6423-6431.

5. Weaver DS (1994) The chemical composition and nutritive value of Australian grain legumes. Grain Research and Development 18: 43-46.

6. Sayed AFM (1999) Alternative dietary protein sources for farmed tilapia Oreochromis spp. Aquaculture 179: 149- 168.

7. Mukherjee R, Nandi B (2004) Improvement of in vivo digestibility through biological treatment of water hyacinth biomass by Pleurotus species. International Biodeterioration and Biodegradation 53: 7-12.

8. Belal EB, Khalafalla MME (2011) Biodegradation of Panicum repens residues by Pleurotus ostreatus for its use as a non-conventional feedstuff in diets of Oreochromis niloticus. Afr J Microbiol Res 5: 3038-3050.

9. Adamovic M, Grubic G, Milenkovic I, Jovanovic R, Protic R, et al. (1998) The biodegradation of wheat straw by Pleurotus ostreatus mushrooms and its use in cattle feeding. Anim. Feed Sci and Technol 71: 357-362.

10. Yildiz S, Yildiz UC, Gezer ED, Temiz A (2002) Some lignocellulosic wastes used as raw material in cultivation of the Pleurotus ostreatus culture mushroom. Process Biochemistry 38: 301-306.

11. Belal EB (2008) Biodegradation of wastepaper by Trichoderma viride and using bioprocessed materials in biocontrol of damping- off of pea caused by Pythium debarymanum. J Agric Res Kafrelsheikh Univ 34: 567-587.

12. Shimeino S, Masumoto T, Hujita T (1993) Alternative protein sources for fish meal diets of young yellowtail. Nippon Suisan Gakkaishi 59: 137-143.

13. AOAC (2000) Association of Official Analytical Chemists. Official Methods of Analysis. AOAC, Arlington, Virginia, USA.

14. NRC (1993) Nutrient requirements of fish. National Academy Press, Washington DC

15. APHA American Public Health Association (1985) Standard methods for the examination of water and waste.

16. Boyd CE (1984) Water Quality in Warm water Fishponds. Auburn University Agriculture Experimental Station, Auburn, AL, USA (Oncorhynchus tshawytscha) and rainbow trout (Oncorhynchus mykiss). Aquaculture 161: 27-43.

17. SPSS (1997) Statistical package for the social sciences..

18. Duncan MB (1955) Multiple ranges and multiple F-tests. Biometrics 11: 1-42.

19. Valizadeh R, Sobhanirad S, Mojtahedi M (2008) Chemical Composition, Ruminal Degradability and in vitro Gas Production of Wheat Straw Inoculated by Pleurotus ostreatus Mushrooms. J Anim Vet Advances 7: 1506-1510.
20. Rzedzicki Z, Sobota A, Zarzycki P (2004) Influence of pea hulls on the twin screw extrusion-cooking process of cereal mixtures and the physical properties of the extrudate. Int Agrophysics 18: 73-81.

21. Rzedzicki Z, Sobota A (2006) Study on the process of single-screw extrusioncooking of mixtures with a content of pea hulls. Int. Agrophysics 20: 327-336

22. Broudiscou LP, Agbagla-Dobnani A, Papon Y, Cornu A, Grenet E, et al. (2003) Rice straw degradation and biomass synthesis by rumen micro-organisms in continuous culture in response to ammonia treatment and legume extract supple mentation. Anim Feed Sci Technol 105: 95-108.

23. Williams BC, McMullan JT, McCahey S (2001) An initial assessment of spent mushroom compost as a potential energy feedstock. Bioresour Technol 79: 227-230.

24. Stickney RR, Shumway SE (1974) Occurrence of cellulose activity in the stomach of fishes. J Fish Biol 6: 779-790.

25. Buddington RK (1980) Hydrolysis-resistant organic matter as a reference for measurement of fish digestion efficiency. Trans Am Fish Soc 109: 653-656.

26. Hassanen GDI, Sherif MA, Hashem NA, Hanafy MA (1995) Utilization of some fermented waste food as a protein source in pelleted feeds for Nile tilapia (Oreochromis niloticus) fingerlings.

27. Jauncey K, Ross B (1982) A guide to tilapia feeds and feeding Ins.

28. Abdolsamad K, Amirkolaie A, Johan J, Johan W (2006) Effect of gelatinization degree and inclusion level of dietary starch on the characteristics of digesta and faeces in Nile tilapia (Oreochromis niloticus (L). Aquaculture 260: 194-205.

29. Gouveia A, Davies SJ (1998) Preliminary evaluation of pea seed meal (Pisum satvum) for juvenile European Sea bass (Dicentrarchus labrax). Aquaculture 166: $311-320$

30. Azaza MS, Wassim K Mensi F Abdelmouleh A, Brini B, Kraïem MM (2009) Evaluation of broad beans (Vicia broad L. var. minuta) as a replacement for soybean meal in practical diets of juvenile Nile tilapia Oreochromis niloticus. Aquaculture 287: 174-179.

31. Leary DF, Lovell RT (1975) Value of fiber in production type diets for channel catfish. Trans Anim Fish Soc 104: 328-332.

32. Shalaby Shymaa MM (2004) Response of Nile tilapia Oreochromis niloticus, fingerlings to diets supplemented with different levels of fenugreek seeds (Hulba). J Agric Sci Mansoura Univ 29: 2231- 2242. 